\title{
Reactive nitrogen oxides and ozone above a taiga woodland
}

\section{Citation}

Bakwin, Peter S., Daniel J. Jacob, Steven C. Wofsy, J. William Munger, Bruce C. Daube, John D. Bradshaw, Scott T. Sandholm, et al. 1994. "Reactive Nitrogen Oxides and Ozone Above a Taiga Woodland." Journal of Geophysical Research 99 (D1): 1927. doi:10.1029/93jd02292.

\section{Published Version}

doi:10.1029/93JD02292

\section{Permanent link}

http://nrs.harvard.edu/urn-3:HUL.InstRepos:14121871

\section{Terms of Use}

This article was downloaded from Harvard University's DASH repository, and is made available under the terms and conditions applicable to Other Posted Material, as set forth at http:// nrs.harvard.edu/urn-3:HUL.InstRepos:dash.current.terms-of-use\#LAA

\section{Share Your Story}

The Harvard community has made this article openly available.

Please share how this access benefits you. Submit a story.

Accessibility 


\title{
Reactive nitrogen oxides and ozone above a taiga woodland
}

\author{
Peter S. Bakwin, ${ }^{1,2}$ Daniel J. Jacob, ${ }^{1}$ Steven C. Wofsy, ${ }^{1}$ J. William Munger, ${ }^{1}$ \\ Bruce C. Daube, ${ }^{1}$ John D. Bradshaw, ${ }^{3}$ Scott T. Sandholm, ${ }^{3}$ Robert W. Talbot, ${ }^{4}$ \\ Hanwant B. Singh, ${ }^{5}$ Gerald L. Gregory, ${ }^{6}$ and Donald R. Blake ${ }^{7}$
}

Measurements of reactive nitrogen oxides $\left(\mathrm{NO}_{x}\right.$ and $\left.\mathrm{NO}_{y}\right)$ and ozone $\left(\mathrm{O}_{3}\right)$ were made in the planetary boundary layer (PBL) above a taiga woodland in northern Quebec, Canada, during June-August, 1990, as part of NASA Artic Boundary Layer Expedition (ABLE) 3B. Levels of nitrogen oxides and $\mathrm{O}_{3}$ were strongly modulated by the synoptic scale meteorology that brought air from various source regions to the site. Industrial pollution from the Great Lakes region of the U.S. and Canada appears to be a major source for periodic elevation of $\mathrm{NO}_{x}, \mathrm{NO}_{y}$ and $\mathrm{O}_{3}$. We find that $\mathrm{NO} / \mathrm{NO}_{2}$ ratios at this site at midday were approximately $50 \%$ those expected from a simple photochemical steady state between $\mathrm{NO}_{x}$ and $\mathrm{O}_{3}$, in contrast to our earlier results from the $A B L E$ 3A tundra site. The difference between the taiga and tundra sites is likely due to much larger emissions of biogenic hydrocarbons (particularly isoprene) from the taiga vegetation. Hydrocarbon photooxidation leads to relatively rapid production of peroxy radicals, which convert $\mathrm{NO}$ to $\mathrm{NO}_{2}$, at the taiga site. Ratios of $\mathrm{NO}_{x}$ to $\mathrm{NO}_{y}$ were typically 2-3 times higher in the PBL during ABLE 3B than during ABLE $3 \mathrm{~A}$. This is probably the result of high PAN levels and suppressed formation of $\mathrm{HNO}_{3}$ from $\mathrm{NO}_{2}$ due to high levels of biogenic hydrocarbons at the ABLE $3 B$ site.

\section{INTRODUCTION}

Recent investigations have suggested that the abundance of ozone $\left(\mathrm{O}_{3}\right)$ is increasing in the troposphere and that the rate of increase is especially rapid at high northern latitudes in summer [Ollmans and Komhyr, 1986; Bojkov, 1988; Ferguson and Rosson, 1992]. Ozone regulates the oxidizing power of the atmosphere and is radiatively active, so that increased ozone levels may have an important influence on atmospheric chemistry and climate. Ozone is also toxic to vegetation, changes in $\mathrm{O}_{3}$ may directly impact the biosphere. Tropospheric $\mathrm{O}_{3}$ levels are regulated primarily by photochemistry, which is sensitively dependent on nitrogen oxide $\left(\mathrm{NO}_{\mathrm{x}}=\mathrm{NO}\right.$ and $\left.\mathrm{NO}_{2}\right)$ mixing ratios [Liu et al., 1987], surface deposition, and by inputs from the stratosphere.

Industrial processes and biomass burning are probably the largest sources of $\mathrm{NO}_{\mathrm{x}}$, with smaller contributions from soil emissions and stratospheric inputs [Logan, 1983]. Photochemistry in the troposphere converts $\mathrm{NO}_{\mathrm{x}}$ to higher oxides, such as $\mathrm{HNO}_{3}$ and organic nitrates. Many of these species are relatively resistant to further photochemical processing and/or deposition and so may be transported over large distances. The thermal and/or photochemical decomposition of some of the higher oxides, especially peroxyacetyl nitrate (PAN) and $\mathrm{HNO}_{3}$, returns $\mathrm{NO}_{\mathrm{x}}$ to the troposphere.

\footnotetext{
1Division of Applied Sciences, Harvard University, Cambridge, Massachusetts.

${ }^{2}$ Now at Climate Monitoring and Diagnostics Laboratory, National Oceanic and Atmospheric Administration, Boulder, Colorado.

${ }^{3}$ School of Atmospheric Sciences, Georgia Institute of Technology, Atlanta, Georgia.

${ }^{4}$ Complex Systems Research Center, University of New Hampshire, Durham.

5NASA Ames Research Center, Moffett Field, California.

6NASA Langley Research Center, Hampton, Virginia.

${ }^{7}$ Department of Chemistry, University of Califomia, Irvine.
}

\section{Copyright 1994 by the American Geophysical Union.}

Paper number 93JD02292.

0148-0227/94/93JD-02292\$05.00
We report measurements of $\mathrm{O}_{3}$ and nitrogen oxide (NO, $\mathrm{NO}_{2}$, and total $\mathrm{NO}_{\mathrm{y}}$ ) mixing ratios in the planetary boundary layer (PBL) of the atmosphere above and within a taiga woodland canopy, at a location remote from anthropogenic sources. The measurements were made during June-August, 1990, as part of NASA Arctic Boundary Layer Expedition (ABLE) 3B. Observations were made on a 31-m-high tower and from the NASA Electra aircraft. Turbulent fluxes of $\mathrm{O}_{3}$ and total $\mathrm{NO}_{\mathrm{y}}$ were also measured at the tower and will be reported in a future publication (J. W. Munger et al., manuscript in preparation, 1993, hereinafter referred to s M93).

Section 2 of this paper focuses on the analytical methods and experimental design used at the tower; other papers in this issue discuss methods used on board the aircraft [Talbot et al., this issue; Sandholm et al., this issue]. Section 3 describes the measurements, and section 4 examines the photochemical steady state for $\mathrm{NO}, \mathrm{NO}_{2}$ and $\mathrm{O}_{3}$ (section 4.1) and $\mathrm{NO}_{x} / \mathrm{NO}_{y}$ ratios (section 4.2). Conclusions are summarized in section 5 .

\section{EXPERIMENT}

Overflights of the ABLE 3B ground site by the NASA Electra airplane were made on six days: Julian days 211 (mission 10), 213 (11), 215 (12), 219 (14), 220 (15), and 223 (17). On day 217 the Electra flew in the PBL somewhat to the southest of Schefferville (mission 13). We will examine observations of $\mathrm{NO}_{\mathbf{x}}$ and $\mathrm{NO}_{\mathrm{y}}, \mathrm{HNO}_{3}, \mathrm{PAN}, \mathrm{O}_{3}, \mathrm{C}_{2} \mathrm{H}_{2}$ and $\mathrm{C}_{2} \mathrm{Cl}_{4}$ obtained in the boundary layer aboard the Electra during these flights. The experimental methods used to obtain these data are given by Talbot et al. [this issue] and Sandholm et al. [this issue], and references therein. The array of $\mathrm{NO}_{\mathrm{y}}$ species $\left(\mathrm{NO}_{\mathrm{x}}, \mathrm{PAN}\right.$ and $\mathrm{HNO}_{3}$ ) and other tracers (hydrocarbons, halocarbons, $\mathrm{CO}$ ) measured aboard the Electra makes the aircraft data set particularly useful for identifying influences on trace gas climatologies, such as industrial pollution and biomass burning [see Wofsy et al., this issue]. We examine aircraft data obtained in the PBL in the region surrounding the Schefferville ground site only; other papers in this issue focus on data obtained above the PBL and over a broader area of 
northeastern Canada and the eastern United States (e.g., Talbot et al., Sandholm et al., Wofsy et al.).

Talbot et al. [this issue] segregate the aircraft data obtained in various altitude intervals with air mass type, on the basis of $\mathrm{CO}$ mixing ratios. We take a different approach and average the PBL data for each aircraft mission to determine the dominant influences on the chemical composition of PBL air during the time period of each flight. We found a high correlation between $\mathrm{C}_{2} \mathrm{H}_{2}$ and $\mathrm{CO}$ in biomass burning and industrial pollution plumes and therefore focus on measurements of $\mathrm{C}_{2} \mathrm{H}_{2}$ as a tracer for burning [see Wofsy et al., this issue]. Mixing ratio data for $\mathrm{CO}$ are not available for much of the flight time in the PBL because the $\mathrm{CO}$ instrument was operated in a fast response mode for eddy flux measurements.

The tower data provide a nearly continuous record of $\mathrm{NO}_{\mathrm{x}}, \mathrm{NO}_{\mathrm{y}}$ and $\mathrm{O}_{3}$ mixing ratios for June 27 to August 17 (Julian days 178 to 229), 1990, and include nighttime and periods of inclement weather during which the aircraft did not fly. Further details of the tower measurements are given below.

The tower measurements were carried out in a black spruce taiga woodland $13 \mathrm{~km}$ northwest of Schefferville, Province de Quebec, Canada $\left(54^{\circ} 50^{\prime} \mathrm{N}, 66^{\circ} 40^{\circ} \mathrm{W}\right.$ ), a town of approximately 3000 inhabitants. No other significant habitations exist within 200 $\mathrm{km}$ of the site. The woodland canopy was open with $\approx 600$ trees $\mathrm{ha}^{-1}$, and the mean canopy height was 5-6 m. A 31-m-high tower (Rohn 25G) was erected and instrumented for chemical and micrometeorological measurements. Chemical analyzers and data acquisition and control computers were located in a tent about 20 $m$ southeast from the base of the tower. Electrical power was provided by a $12.5-\mathrm{kVA}$ diesel generator located $300 \mathrm{~m}$ southeast of the tower.

The experimental design was similar to that described by Bakwin et al. [1992]. Mixing ratios and turbulent fluxes of $\mathrm{NO}_{\mathrm{y}}$ and $\mathrm{O}_{3}$ were measured at 29 and $31 \mathrm{~m}$ height, respectively. Mixing ratios of $\mathrm{O}_{3}$, $\mathrm{NO}$ and $\mathrm{NO}_{2}$ were measured by sampling through $0.635 \mathrm{~cm}$ OD. Teflon tubes with inlets fixed at $0.05,0.85,2.8,6.2$, $9.5,18.2$, and $30.8 \mathrm{~m}$ height on or near the tower. The sampling sequence was from highest to lowest, each location was sampled for $4 \mathrm{~min}$ during each profile. The $\mathrm{NO}_{\mathrm{x}}$ detector was zeroed following sampling from the $0.05-\mathrm{m}$ tube.

Reactive nitrogen oxides $\left(\mathrm{NO}_{\mathrm{y}}\right)$ were converted to $\mathrm{NO}$ by goldcatalyzed reaction with $\mathrm{H}_{2}$ at $300^{\circ} \mathrm{C}$ [Fahey et al., 1986] and quantified using chemiluminescence with $\mathrm{O}_{3}$. The converter consisted of a $90-\mathrm{cm}$-long, $0.635 \mathrm{~cm}$ D gold-plated $(2.5 \mu \mathrm{m}$ thickness) copper tube and was located at the inlet end of the sampling tube. Calibration gases and $\mathrm{H}_{2}$ were added to the sample air through two $0.16-\mathrm{cm}$-OD stainless steel tubes that intruded several centimeters into the inlet of the converter tube. The converter design minimized instrument response time to $\mathrm{NO}_{\mathrm{y}}$ species by minimizing contact of sample air with nonconverting surfaces [Bakwin et al. 1992; M93]. The instrument responded to a pulse input of $\mathrm{HNO}_{3}$ with a $90 \%$ risetime under $2 \mathrm{~s}$.

After passing through the converter, sample air passed through $\approx 40 \mathrm{~m}$ of $0.635-\mathrm{cm}-\mathrm{OD}$ Teflon tubing to the NO analyzer. Sample flow rate was $900 \mathrm{~cm}^{3} \mathrm{~min}^{-1}$ STP ( $\mathrm{cm}^{3}$ STP). An instrument zero was obtained every $40 \mathrm{~min}$ by addition of $50 \mathrm{~cm}^{3}$ STP of "zero" air containing $=100$ ppmv (parts per million by volume) $\mathrm{O}_{3}$ (generated using a $\mathrm{Hg}$ vapor lamp) to the sample air just downstream of the converter, so that $\mathrm{NO}$ was converted to $\mathrm{NO}_{2}$. Calibrations for NO were carried out every 3 hours by addition to the sample air at the inlet of the converter of $\approx 2 \mathrm{~cm}^{3}$ STP of a National Institute for Standards and Technology (NIST) (Gaithersburg, Maryland) traceable standard gas containing $4.42 \mathrm{ppmv}$ NO in $\mathrm{N}_{2}$.

Checks on the conversion efficiency for $\mathrm{NO}_{2}$ were performed twice daily. For an efficiency check the NO standard was added to $50 \mathrm{~cm}^{3}$ STP of "zero" air containing $\approx 2 \mathrm{ppmv} \mathrm{O}_{3}$ in a $4 \mathrm{~cm}^{3}$ volume just before being introduced into the converter, so that $\approx 99 \%$ of $\mathrm{NO}$ was converted to $\mathrm{NO}_{2}$. The conversion efficiency remained $>95 \%$ for the full observation period. No measurements of the conversion efficiency for higher $\mathrm{N}$ oxides were done in the field. In laboratory tests using $\mathrm{HNO}_{3}$ in humidified "zero" air, efficient conversion to NO was obtained at sample flow rates up to $5000 \mathrm{~cm}^{3}$ STP. Also, conversion efficiency for $\mathrm{NH}_{3}$ in humidified air ( $>20 \%$ relative humidity $(\mathrm{RH})$ at $23^{\circ} \mathrm{C}$ ) was found to be negligible in agreement with results from other laboratories (G. Hubler, personal communication, 1990).

Occasionally local pollution (mainly from the generator) was sampled at the tower. During these periods the variance of the $\mathrm{NO}_{\mathrm{y}}$ measurements was greatly increased (coefficient of variation $>2$ for a 5 -min period), so that such intervals were easily identified and were removed from the data set.

A separate detector was used to measure mixing ratios of NO and $\mathrm{NO}_{2}$. Nitric oxide was measured by chemiluminescence with $\mathrm{O}_{3}$, and $\mathrm{NO}_{2}$ was measured following photolysis to $\mathrm{NO}$ [Bakwin et al., 1992] in a $165 \mathrm{~cm}^{3}$ quartz cell at a sample airflow rate of 800 $\mathrm{cm}^{3}$ STP and pressure of 300 torr. The reduced pressure in the photolysis cell minimized the conversion of $\mathrm{NO}$ to $\mathrm{NO}_{2}$ by ambient $\mathrm{O}_{3}$ [Ridley et al., 1988; Bakwin et al,, 1992]. During sampling from each altitude, 2 min were spent in an NO mode and 2 min were spent in an $\mathrm{NO}_{2}$ (photolysis) mode.

To zero the $\mathrm{NO}_{\mathrm{x}}$ detector, a solenoid valve was used to introduce a flow of $50 \mathrm{~cm}^{3}$ STP "zero" air containing $\approx 100 \mathrm{ppmv}$ of $\mathrm{O}_{3}$ to the sample air just upstream of the quartz cell, with no photolysis, so that NO was removed. At night, reaction with ambient $\mathrm{O}_{3}$ is expected to completely remove NO, providing a check on the zeroing procedure. The mean (standard deviation) nighttime NO mixing ratio for 2.8 to $30.8 \mathrm{~m}$ was $0.2(1.1, n=2124)$ pptv (parts per trillion by volume), with no significant difference between sampling heights (see Figure 3 ). Nitric oxide mixing ratios at $0.05 \mathrm{~m}$ were elevated somewhat due to emission of NO from the surface (see below). Previously, we reported an artifact of $\approx 1.7$ pptv for our NO measurements [Bakwin et al., 1992]. Introduction of a solenoid valve to switch the $\mathrm{O}_{3}$-laden zeroing air in and out of the sample airstream appears to have eliminated this artifact ( $<0.5$ pptv).

Calibrations for $\mathrm{NO}$ and $\mathrm{NO}_{2}$ were performed every 3 hours using the methods described by Bakwin et al. [1992]. The NO (compressed gas) and $\mathrm{NO}_{2}$ (permeation tube) calibration standards were compared in the field using gold-catalyzed reaction with $\mathrm{H}_{2}$ to completely convert $\mathrm{NO}_{2}$ to $\mathrm{NO}$. The $\mathrm{NO}$ standard was considered the primary standard in the field and was referenced before and after the field campaign to two NIST standards maintained in our laboratory. No significant change was observed in the working stardard between these two comparisons. Estimates of the precision and accuracy of the $\mathrm{NO}$ and $\mathrm{NO}_{2}$ measurements are given by Bakwin et al. [1992].

An ultraviolet (UV) photometer (Dasibi 1003-AH) was used to determine $\mathrm{O}_{3}$ mixing ratios. The zero level of the photometer was determined frequently by passing the sample air through a screen 
impregnated with $\mathrm{MnO}_{2}$ and was found to be stable to better than \pm 0.5 ppbv (parts per billion by volume) during the field experiment. To ensure a consistent calibration for ground and aircraft ozone observations, the photometer was compared in the field to a similar instrument calibrated at NASA Langley Research Center. Ozone was also measured continuously at $30.8 \mathrm{~m}$ height using a Bendix $\mathrm{C}_{2} \mathrm{H}_{4}$-chemiluminescence detector that was modified for fast response, and the data were used to compute turbulent fluxes of $\mathrm{O}_{3}$ (M93).

Solar UV radiation was measured at the tower site using a radiometer identical to those flown on the Electra (Eppley Laboratory, Newport, Rhode Island). The radiometer was mounted on a pole at $6.1 \mathrm{~m}$ height, just above the tops of most nearby trees (5-6 $\mathrm{m}$ high). The radiometer output was used to compute the photolysis rate for $\mathrm{NO}_{2}, \mathrm{~J}_{\mathrm{NO}_{2}}$, following Madronich [1987]:

$$
\mathrm{J}_{\mathrm{NO}_{2}}=1.35 \mathrm{E}\left[\frac{1}{(0.56+0.03 \mathrm{Z}) \cos \mathrm{X}_{\mathrm{o}}+0.21-0.015 \mathrm{Z}}+2 \mathrm{~A}\right](1)
$$

where $\mathrm{E}$ is the radiometer signal $\left(\mathrm{mW} \mathrm{cm} \mathrm{cm}^{-2}\right), \mathrm{X}_{\mathrm{o}}$ is the solar zenith angle, $A$ is the albedo for $U V$ radiation, and $Z$ is the station elevation ( $0.5 \mathrm{~km}$ above sea level). The UV albedo was obtained from extrapolation to the surface of the ratio of nadir to zenith looking UV radiometer readings taken aboard the Electra during lowaltitude overflights of the ground site $(670-1300 \mathrm{~m}$ above sea level), giving $A=0.03$. For $X_{0}<70^{\circ}$, equation (1) is expected to yield values for $\mathrm{J}_{\mathrm{NO}_{2}}$ accurate to $\pm 20 \%$ for both clear and overcast skies [Madronich, 1987; Shetter et al., 1992].

Samples for hydrocarbon and halocarbon analysis were obtained at 10 and $30 \mathrm{~m}$ height on the tower on Julian days 220-224. Methods used for sample collection and analysis were similar to those used for aircraft sampling [Blake et al., this issue]. We discuss here results for acetylene $\left(\mathrm{C}_{2} \mathrm{H}_{2}\right)$, perchloroethylene $\left(\mathrm{C}_{2} \mathrm{Cl}_{4}\right)$, and isoprene.

\section{OBSERVATIONS}

\subsection{Mixing Ratios of $\mathrm{NO}_{x}, \mathrm{NO}_{y}$, and $\mathrm{O}_{3}$}

Hourly mean mixing ratios of $\mathrm{NO}_{\mathrm{k}}, \mathrm{NO}_{\mathrm{y}}$, and $\mathrm{O}_{3}$ at $30 \mathrm{~m}$ above the surface ranged from 15 to $>150 \mathrm{pptv},<50$ to $>1500 \mathrm{pptv}$, and 5 to $49 \mathrm{ppbv}$, respectively (Figure 1). The mean and median diurnal cycles for $\mathrm{NO}_{x}, \mathrm{NO}_{y}$, and $\mathrm{O}_{3}$ at $30 \mathrm{~m}$ height are shown in Figure 2. Maximum $\mathrm{NO}_{y}$ and $\mathrm{O}_{3}$ levels, typically about 270 pptv and 28 ppbv, respectively, were observed near midday, coincident with the maximum rate of vertical mixing. At night, $\mathrm{NO}_{y}$ and $\mathrm{O}_{3}$ levels in the surface layer were depressed due to deposition and decoupling from the atmosphere above (M93). Mixing ratios of $\mathrm{NO}_{\mathrm{x}}$ were also somewhat lower at night than in the daytime. The nighttime loss rate for $\mathrm{NO}_{\mathrm{x}}$ (about $1.3 \mathrm{pptv} \mathrm{h}^{-1}$ on average) probably reflects net deposition to the surface (see below) as well as reaction of $\mathrm{NO}_{2}$ with $\mathrm{O}_{3}$ to form $\mathrm{NO}_{3}$, which may be lost by deposition or via further reactions.

Statistics for $\mathrm{NO}_{\mathbf{x}}, \mathrm{NO}_{\mathbf{y}}$, and $\mathrm{O}_{3}$ mixing ratios during midday (1000-1600 eastern standard time (EST)) for Julian days 178 to 229, 1990, are given in Table 1. Probability distributions for $\mathrm{NO}_{\mathbf{x}}$ and $\mathrm{NO}_{\mathrm{y}}$ were somewhat skewed due to a relatively small number of observations with very high mixing ratios: median $\mathrm{NO}_{\mathrm{x}}$ and $\mathrm{NO}_{\mathrm{y}}$ mixing ratios were lower than the means. The $\mathrm{O}_{3}$ data were more nearly normally distributed.
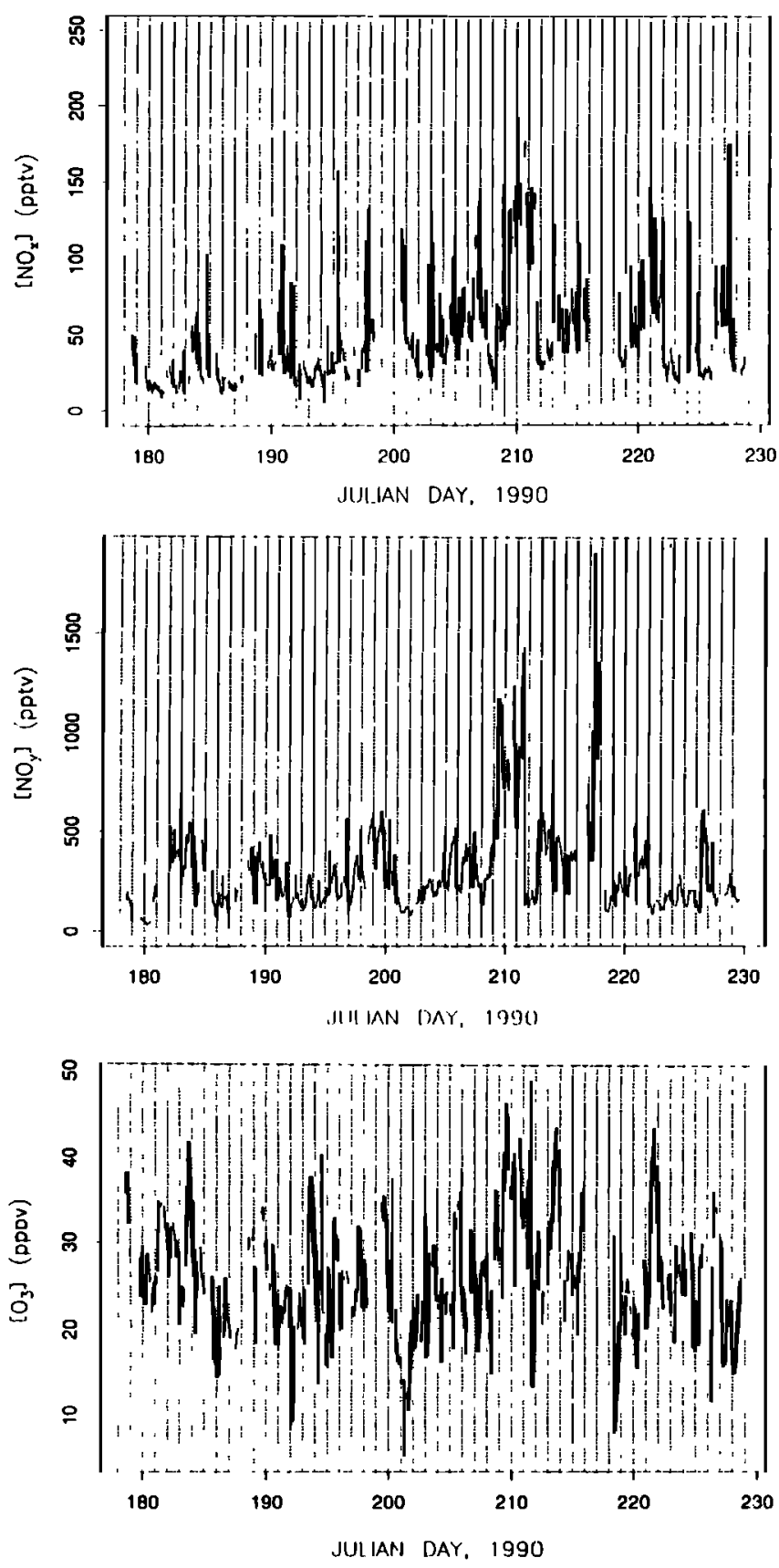

Fig. 1. Time series of (a) $\mathrm{NO}_{x},(b) \mathrm{NO}_{y}$, and $(c) \mathrm{O}_{3}$ mixing ratios at $31 \mathrm{~m}$ height above the ground on the Schefferville tower.

Fitzjarrald and Moore [this issue] discuss climatological changes that occurred during the period of our observations. They report a shift in the synoptic regime around Julian day 197 , from a cool period of frequent precipitation and westerly to northwesterly flow to a warmer, drier period characterized by southwesterly flow and generally deeper afternoon boundary layers. A return to cooler weather and westerly to northwesterly flow occurred about day 221. These changes in climate are reflected in the $\mathrm{NO}_{\mathbf{x}}$ and $\mathrm{NO}_{\mathrm{y}}$ mixing ratios (Figure 1); on average, higher daytime levels were observed during the period of generally southwesterly flow than during the cooler periods (Table 1). Ozone levels were not significantly correlated with the climatological changes.

Figure 3 shows the mean vertical distributions $(0.05$ to $31 \mathrm{~m})$ of $\mathrm{NO}, \mathrm{NO}_{2}, \mathrm{NO}_{\mathrm{x}}$, and $\mathrm{O}_{3}$ at each height for nighttime (2000-0400 

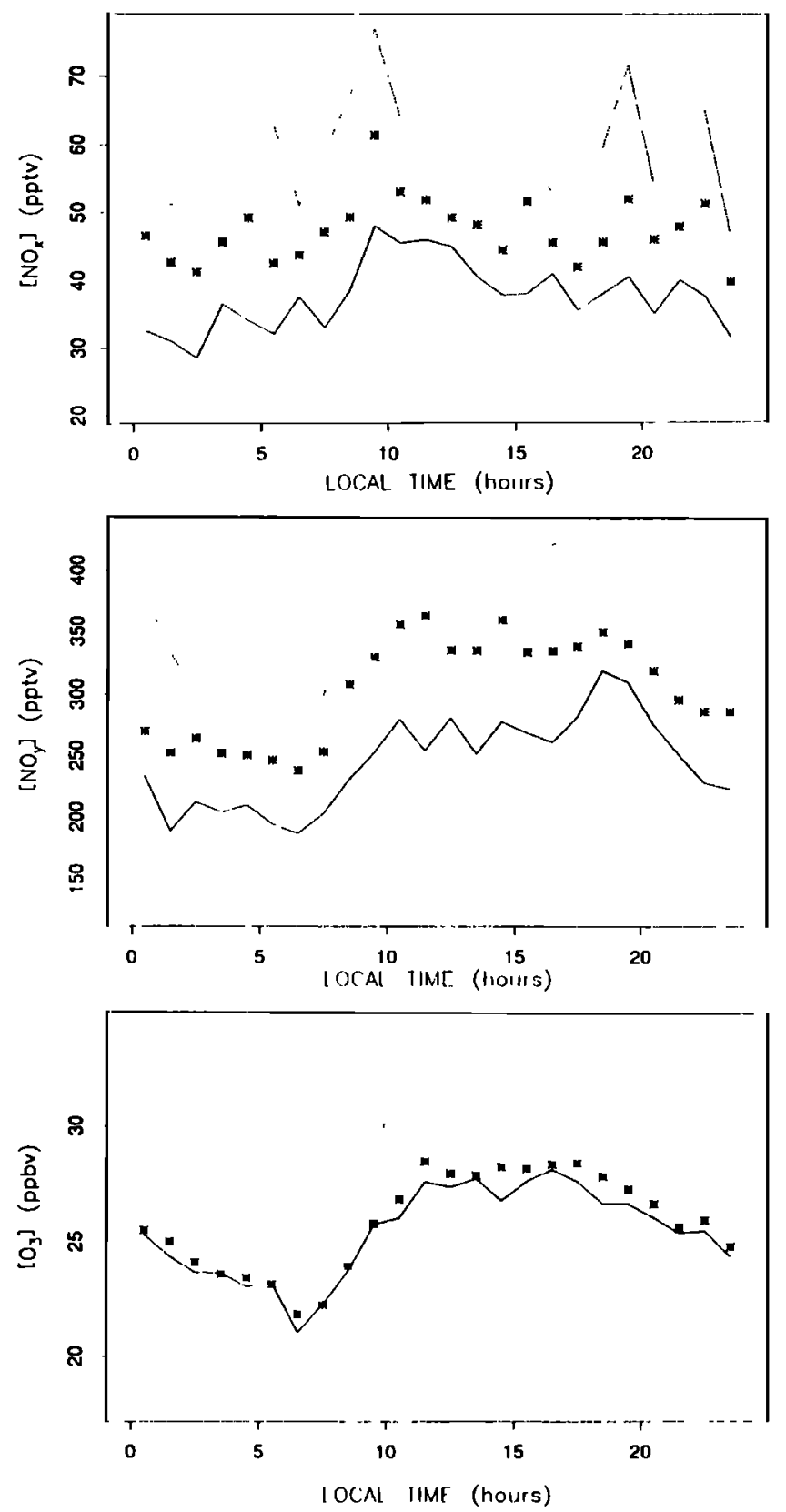

Fig. 2. Median (solid curves) and mean (asterisks) diumal cycles of (a) $\mathrm{NO}_{\mathrm{x}}$, (b) $\mathrm{NO}_{\mathrm{y}}$, and (c) $\mathrm{O}_{3}$ mixing ratios at $31 \mathrm{~m}$ height above the ground on the tower. Upper and lower quartiles are shown by dotted curves.

EST) and midday (1000-1600 EST). Ozone was depleted at the lowest altitudes due to surface uptake, which was strongest during the daytime (M93). Mixing ratios of NO were somewhat elevated at $0.05 \mathrm{~m}$ height compared to other altitudes, indicating that $\mathrm{NO}$ was emitted from the surface. The emission rates for NO consistent with the observed gradients are very small, less than $1 \times$ $10^{8}$ molecules $\mathrm{cm}^{-2} \mathrm{~s}^{-1}$. During the daytime, emissions of $\mathrm{NO}$ from the soil appear to have been about balanced by deposition of $\mathrm{NO}_{2}$ to the plant canopy and ground, resulting in little overall vertical gradient for $\mathrm{NO}_{\mathrm{x}}$, while at night $\mathrm{NO}_{2}$ deposition slightly exceeded NO emission. The net flux of $\mathrm{NO}_{\mathrm{x}}$ at night $\left(\mathrm{F}_{\mathrm{NO}}\right)$ can be estimated as [Bakwin et al., 1992]

$$
\mathrm{F}_{\mathrm{NO}}=\mathrm{F}_{\mathrm{O}_{3}} \frac{\mathrm{d}\left[\mathrm{NO}_{\mathrm{x}}\right] / \mathrm{dz}}{\mathrm{d}\left[\mathrm{O}_{3}\right] / \mathrm{dz}}
$$

At night, $\mathrm{F}_{\mathrm{O}_{3}}$ averaged about $5 \times 10^{10}$ molecules $\mathrm{cm}^{-2} \mathrm{~s}^{-1}$ (M93), the $\mathrm{NO}_{\mathrm{x}}$ and $\mathrm{O}_{3}$ gradients $(30.8-0.05 \mathrm{~m})$ were roughly 5 pptv and 15 ppbv, respectively (Figure 3), yielding $\mathrm{F}_{\mathrm{NO}}=1.7 \times 10^{7}$ molecules $\mathrm{cm}^{-2} \mathrm{~s}^{-1}$, or assuming a 100 -m-deep nocturnal stable layer, about $0.3 \mathrm{pptv} \mathrm{h}^{-1}$, roughly $20 \%$ of the observed nighttime loss rate for $\mathrm{NO}_{\mathrm{x}}$.

\subsection{Pollution Influences}

The time series of $\mathrm{NO}_{x}, \mathrm{NO}_{y}$, and $\mathrm{O}_{3}$ (Figure 1) clearly show coherent variations, $\approx 1$ (e.g., day 195) to 8 (e.g., days 193 to 201) days duration, correlated with surface pressure changes indicating the influence of synoptic scale air mass characteristics. Typically, $\mathrm{NO}_{x}, \mathrm{NO}_{y}$, and $\mathrm{O}_{3}$ were enhanced during periods of falling surface pressure, which tended to be associated with air originating from the southwest quadrant, according to 5-day back trajectories for surface air. Mixing ratios were relatively low during periods of rising pressure, most often associated with trajectories from the $\mathrm{N}$ hemicircle, indicating Arctic air. Regions to the southwest were apparently significant sources of $\mathrm{NO}_{x}, \mathrm{NO}_{y}$, and $\mathrm{O}_{3}$ at the surface.

Mixing ratios of $\mathrm{NO}_{x}$ and $\mathrm{NO}_{y}$ measured at the tower appear to have been somewhat higher than those measured simultaneously aboard the aircraft. Direct comparison is difficult since the aircraft data represent means taken over many kilometers, and because of the small number of data points. The ground site may have been located in a zone of somewhat elevated $\mathrm{N}$ oxide levels due to natural processes or local anthropogenic pollution. However, the overall agreement of $\mathrm{NO}_{x} / \mathrm{NO}_{y}$ ratios between the ground site and the airplane (see below and Figure 7) indicate that local pollution was probably not a significant problem at the ground site.

Table 2 shows mixing ratios of $\mathrm{C}_{2} \mathrm{H}_{2}, \mathrm{C}_{2} \mathrm{Cl}_{4}, \mathrm{NO}_{\mathrm{y}}$, and $\mathrm{O}_{3}$ on the tower and from the Electra (PBL only) for selected flights. Acetylene is emitted by biomass and fossil fuel burning and has a lifetime of in the troposphere of 2-3 weeks, while $\mathrm{C}_{2} \mathrm{Cl}_{4}$ is a purely industrial product with a lifetime of 12-14 weeks. Mixing ratios of $\mathrm{NO}_{y}$ and $\mathrm{O}_{3}$ at the ground site were near or below their daytime background values of 247 pptv and 28 ppbv (as defined by medians for days 178-196; see Table 1), respectively, on days 215,219 ,

TABLE 1. Statistics for Observed $\mathrm{NO}_{\mathrm{x}}, \mathrm{NO}_{\mathrm{y}}$ and $\mathrm{O}_{3}$ Mixing Ratios Measured at $30 \mathrm{~m}$ Height on the Schefferville Tower

\begin{tabular}{cccccccccccccrrr}
\hline $\begin{array}{c}\text { Interval } \\
1990\end{array}$ & Mean & s.d. & Median & LQ & UQ & \multicolumn{1}{c}{$\mathbf{n}$} & Mean & s.d. & Median & LQ & UQ & $\mathbf{n}$ & Mean & s.d. & $\mathbf{n}$ \\
\hline $178-229$ & 49 & 30 & 41 & 27 & 60 & 185 & 343 & 273 & 269 & 182 & 401 & 256 & 28 & 7 & 201 \\
$178-196$ & 31 & 14 & 27 & 20 & 40 & 71 & 261 & 110 & 247 & 180 & 337 & 84 & 28 & 5 & 75 \\
$197-221$ & 66 & 31 & 57 & 44 & 80 & 90 & 434 & 346 & 342 & 237 & 470 & 126 & 28 & 9 & 97 \\
$222-229$ & 41 & 31 & 28 & 26 & 42 & 24 & 228 & 130 & 189 & 158 & 218 & 46 & 26 & 5 & 29 \\
\hline
\end{tabular}

LQ denotes lower quartile; s.d. denotes standard deviation; UQ denotes upper quartile; $n$, number of observations. 

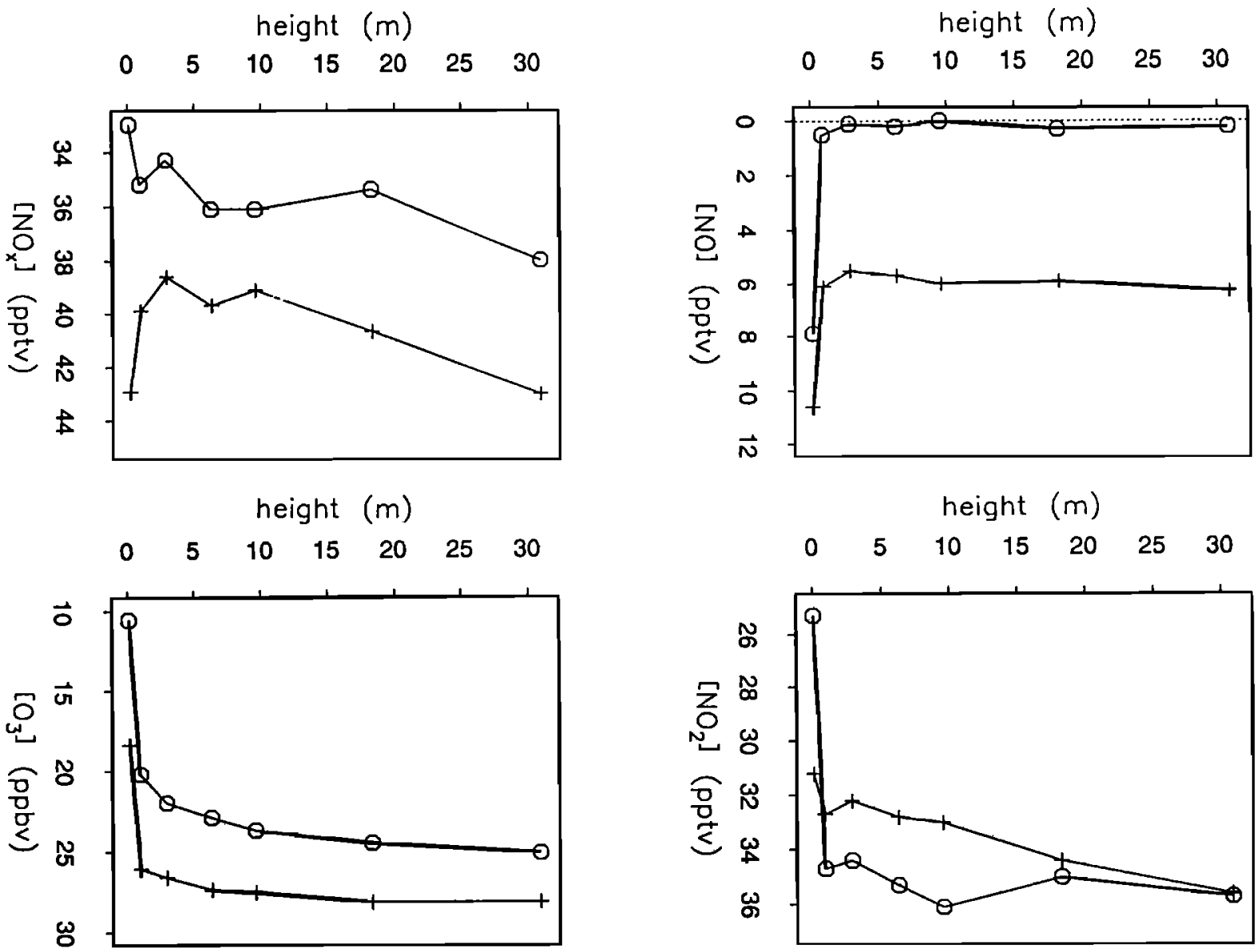

Fig. 3. Mean mixing ratios of $\mathrm{NO}, \mathrm{NO}_{2}, \mathrm{NO}_{\mathrm{x}}$, and $\mathrm{O}_{3}$ at each sampling height on the tower for daytime (pluses, 1000 to 1600 EST) and nighttime (circles, 2000 to $0400 \mathrm{EST}$ ) (Julian days 178-228). Observations lying more than 1.5 times the interquartile distance from the upper and lower quartiles (see Figure 2) have been excluded from the means.

$220,222,223$, and 224 , which include the time periods for aircraft missions $12,14,15$, and 17 . These species were significantly above background levels on days 211, 213, and 221, and also $\mathrm{C}_{2} \mathrm{Cl}_{4}$ mixing ratios exceeded apparent "background" levels of 9.7-12.7 pptv (range of data taken on other days) on days 211 (mission 10) and 221 (no aircraft flight over the ground site). During aircraft mission $10, \mathrm{C}_{2} \mathrm{Cl}_{4}$ and $\mathrm{C}_{2} \mathrm{H}_{2}$ mixing ratios in the $\mathrm{PBL}$ over our site reached levels comparable to those observed in the polluted PBL over midlatitude areas during mission 22, indicating that the air sampled was strongly influenced by anthropogenic sources. Elevated mixing ratios of $\mathrm{NO}_{x}, \mathrm{NO}_{y}$, and $\mathrm{O}_{3}$ were observed at the ground site for about 2.5 days prior to mission 10 , indicating that the pollution source was regional, and 5-day back trajectories show that air that reached the site during mission 10 had passed over the Great Lakes region of the United States and Canada (trajectories are presented by Shipham et al. [this issue]), a

TABLE 2a. Mixing Ratios of $\mathrm{C}_{2} \mathrm{H}_{2}, \mathrm{C}_{2} \mathrm{Cl}_{4}, \mathrm{NO}_{\mathrm{y}}, \mathrm{O}_{3}$, and $\mathrm{NO}_{\mathrm{x}}$ Obtained on the NASA Electra Airplane and on the Schefferville Tower During Overflights by the Electra

\begin{tabular}{|c|c|c|c|c|c|c|c|c|c|}
\hline \multirow[b]{2}{*}{$\begin{array}{l}\text { JDAY, } \\
1990 \\
\end{array}$} & \multicolumn{6}{|c|}{ Aircraft } & \multicolumn{3}{|c|}{ Tower } \\
\hline & $\overline{\text { FLT }}$ & $\begin{array}{c}\overline{\mathrm{C}}_{2} \overline{\mathrm{H}}_{2}, \\
\mathrm{pptv}\end{array}$ & $\begin{array}{c}\mathrm{C}_{2} \mathrm{Cl}_{4}, \\
\text { pptv }\end{array}$ & $\begin{array}{l}\mathrm{NO}_{\mathrm{y}}, \\
\text { pptv }\end{array}$ & $\begin{array}{l}\mathrm{O}_{3}, \\
\mathrm{ppbv}\end{array}$ & $\begin{array}{l}\mathrm{NO}_{\mathrm{x}}, \\
\text { pptv }\end{array}$ & $\begin{array}{l}\mathrm{NO}_{\mathrm{y}}, \\
\text { pptv }\end{array}$ & $\begin{array}{c}\mathrm{O}_{3}, \\
\text { ppbv }\end{array}$ & $\begin{array}{l}\mathrm{NO}_{\mathrm{x}}, \\
\mathrm{pptv}\end{array}$ \\
\hline$\overline{211^{a}}$ & 10 & 313 & 31.8 & 877 & 52 & 151 & 1429 & 49 & 229 \\
\hline 213 & 11 & 70 & 12.4 & 312 & 43 & 31 & 408 & 40 & 65 \\
\hline 215 & 12 & 115 & 10.8 & nd & 27 & nd & 233 & 23 & 49 \\
\hline $217^{b}$ & 13 & 106 & 11.4 & 209 & 24 & 33 & nd & nd & nd \\
\hline 219 & 14 & 83 & 10.5 & 133 & 28 & 31 & 267 & 24 & 55 \\
\hline 220 & 15 & 83 & 9.7 & 202 & 20 & 38 & 256 & 21 & 69 \\
\hline 223 & 17 & 70 & 11.9 & 112 & 25 & 31 & 188 & 27 & 39 \\
\hline $227^{c}$ & 22 & 337 & 46.6 & 3798 & 68 & 728 & & & \\
\hline
\end{tabular}

Here nd denotes no data.

${ }^{a}$ Schefferville spiral only.

${ }^{b}$ Flight southeast of Schefferville.

${ }^{c}$ Transit flight (midlatitudes). 
TABLE $2 b$. Tower Data for Intervals When Grab Samples Were Taken for Hydrocarbon/Halocarbon Analysis

\begin{tabular}{lrcccc}
\hline $\begin{array}{l}\text { JDAY, } \\
1990\end{array}$ & $\begin{array}{r}\mathrm{C}_{2} \mathrm{H}_{2}, \\
\text { pptv }\end{array}$ & $\begin{array}{c}\mathrm{C}_{2} \mathrm{Cl}_{\mathbf{4}}, \\
\text { pptv }\end{array}$ & $\begin{array}{c}\mathrm{NO}_{\mathrm{y}}, \\
\text { pptv }\end{array}$ & $\begin{array}{c}\mathrm{O}_{3}, \\
\text { ppbv }\end{array}$ & $\begin{array}{c}\mathrm{NO}_{\mathbf{x}}, \\
\text { pptv }\end{array}$ \\
\hline 220 & 99 & 10.2 & 276 & 21 & 66 \\
221 & 125 & 16.3 & 334 & 38 & 67 \\
222 & 72 & 11.7 & 125 & 24 & 28 \\
223 & 67 & 12.4 & 172 & 27 & 36 \\
224 & 65 & 12.7 & 235 & 29 & nd \\
\hline
\end{tabular}

highly industrialized area. The enhancements of $\mathrm{C}_{2} \mathrm{Cl}_{4}$ and $\mathrm{C}_{2} \mathrm{H}_{2}$ at the tower on day 221 were much smaller, indicating that anthropogenic pollution, though present, was more dilute than during the episode of days 209-211. These results indicate that distant industrial sources had a pronounced influence on $\mathrm{NO}_{x}, \mathrm{NO}_{\mathbf{y}}$, and $\mathrm{O}_{3}$ levels observed at the ground site. The higher mixing ratios of $\mathrm{O}_{3}$ in the polluted air masses most likely reflect net photochemical production (or suppressed destruction) in the presence of elevated $\mathrm{NO}_{\mathrm{x}}$.

Enhancements of $\mathrm{C}_{2} \mathrm{H}_{2}$ (and other hydrocarbons) observed on days 217 (mission 13) and 220 were not associated with increased $\mathrm{C}_{2} \mathrm{Cl}_{4}$ or $\mathrm{NO}_{\mathrm{y}}$ and hence were most likely due to boreal biomass fires. Detailed investigations of biomass burning and industrial pollution plumes observed from the Electra over Alaska (ABLE 3A [Wofsy et al., 1992]) and northeastem Canada (ABLE 3B [Talbot et al., this issue; Wofsy et al., this issue]) show that $\mathrm{NO}_{\mathrm{y}} / \mathrm{CO}$ and $\mathrm{NO}_{\mathrm{y}}$ /hydrocarbon emission ratios are low in biomass fires compared to industrial emissions.

Jacob et al. [1993] have used a chemical tracer model (CTM), with transport fields from the Goddard Institute for Space Studies global circulation model [Hanson et al., 1983], and with parameterized photochemistry [Spivakovsky et al., 1990], to simulate mixing ratios of $\mathrm{O}_{3}$ and its precursors over North America. The model produces mixing ratios of $\mathrm{O}_{3}, \mathrm{NO}_{x}$, and $\mathrm{CO}$ in general agreement with observations taken at a number of sites throughout the United States, and successfully simulates episodes of high $\mathrm{O}_{3}$ in the eastern United States that occur during periods of stagnant meteorology in summer (see Jacob et al. [1993] for details).

Table 3 compares the frequency distributions for $\mathrm{NO}_{x}$ generated from the model for 1430 EST during June-August in the $\left(4^{\circ} \times 5^{\circ}\right)$ grid cell containing the Schefferville tower, with those observed at the tower (1000-1600 EST). We compare the model results and observations for daytime only because at night the observed mixing ratios are somewhat depleted below the shallow inversion by surface deposition and chemistry (see Figure 2). The observed NO mixing ratios are 10-24 pptv higher than the model for each percentile. Since the only sources for $\mathrm{NO}_{\mathrm{x}}$ in the model are industrial, these results indicate that "background" $\mathrm{NO}_{\mathrm{x}}$ levels at the Schefferville site (i.e., air masses that are unaffected by recent $\mathrm{NO}_{\mathbf{x}}$ inputs) are in the range of 10-24 pptv. This interpretation is

TABLE 3. Observed and Simulated (CTM) $\mathrm{NO}_{\mathrm{x}}$ (pptv) Frequency Distributions at the Schefferville Site

\begin{tabular}{ccc}
\hline Percentile & Observations & Model \\
\hline 5 & 18 & 2 \\
17 & 24 & 2 \\
50 & 42 & 18 \\
83 & 72 & 58 \\
95 & 120 & 110 \\
\hline
\end{tabular}

CTM, chemical tracer model. supported by our data from the ABLE 3A tundra site [Bakwin et al., 1992], where $\mathrm{NO}_{\mathrm{x}}$ mixing ratios were typically $12 \pm 4 \mathrm{pptv}$ and were apparently little affected by recent emissions. The frequency distribution for $\mathrm{NO}_{\mathrm{x}}$ in the model agrees well with the observations at the high percentiles, and the model time series (not shown) shows episodes of elevated $\mathrm{NO}_{\boldsymbol{x}}$ and $\mathrm{O}_{3}$ of similar magnitude and duration to those observed (Figure 1), indicating that the transport of $\mathrm{NO}_{\mathrm{x}}$ (or $\mathrm{NO}_{\mathrm{x}}$ precursors such as PAN) from industrial sources is realistically simulated for this site.

The model predicts large northward transport of $\mathrm{NO}_{\mathbf{x}}$ and $\mathrm{O}_{3}$ in the PBL at $54^{\circ} \mathrm{N}$ over eastern Canada during July and negligible transport of $\mathrm{NO}_{x}$ and $\mathrm{O}_{3}$ above the PBL. Examination of the model time series for $\mathrm{NO}_{\mathrm{x}}$ and $\mathrm{O}_{3}$ over the eastem United States and Canada reveals that these species are transported to Schefferville episodically during the approach of low-pressure systems, in harmony with our observations of generally elevated $\mathrm{NO}_{\mathrm{x}}, \mathrm{NO}_{\mathbf{y}}$, and $\mathrm{O}_{3}$ levels during periods of falling pressure. These periods are characterized by subsidence over the study area, which acts to confine industrial pollution within the PBL [Fitzjarrald and Moore, this issue].

\section{INFLUENCE OF PHOTOCHEMISTRY ON NO $\mathrm{N}_{\mathrm{x}}$ AND RADICALS}

\subsection{Photochemical Steady State for $\mathrm{NO}_{x}$ and $\mathrm{O}_{3}$}

During the daytime, $\mathrm{NO}, \mathrm{NO}_{2}$, and $\mathrm{O}_{3}$ are cycled on a timescale of minutes by the reactions

$$
\begin{aligned}
& \mathrm{NO}+\mathrm{O}_{3} \rightarrow \mathrm{NO}_{2}+\mathrm{O}_{2} \\
& \mathrm{NO}_{2}+\mathrm{hv} \rightarrow \mathrm{NO}+\mathrm{O} \\
& \mathrm{O}+\mathrm{O}_{2}+\mathrm{M} \rightarrow \mathrm{O}_{3}+\mathrm{M}
\end{aligned}
$$

where hv represents photons with wavelengths $<420 \mathrm{~nm}$. If isolated from strong sources or sinks for $\mathrm{NO}_{2}$ or $\mathrm{O}_{3}$, these reactions may reach a photochemical steady state such that

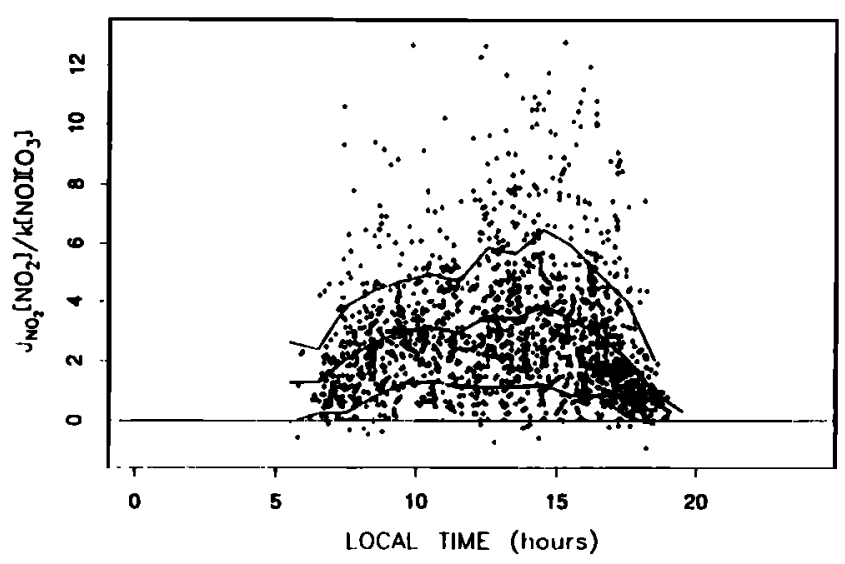

Fig. 4. Value of $\mathrm{P}=\mathrm{J}_{\mathrm{NO}_{2}}\left[\mathrm{NO}_{2}\right] / \mathrm{k}[\mathrm{NO}]\left[\mathrm{O}_{3}\right]$, which bas been computed from measurements of $\mathrm{NO}, \mathrm{NO}_{2}, \mathrm{O}_{3}$, temperature $(\mathrm{k})$, and the output of a $\mathrm{UV}$ radiometer $\left(\mathrm{J}_{\mathrm{NO}_{2}}\right)$, plotted against time of day. Hourly means $( \pm 1$ s.d.) are shown by the dotted curves. Points with $\mathrm{P}<-1$ or $\mathrm{P}>13$ have been excluded based on examination of the probability distribution function for the data (52 out of 1799 points). 


$$
\mathrm{P}=\frac{\mathrm{J}_{\mathrm{NO}_{2}}\left[\mathrm{NO}_{2}\right]}{\mathrm{k}[\mathrm{NO}]\left[\mathrm{O}_{3}\right]}
$$

where $\mathbf{k}$ is the rate constant for (3) and is a function only of temperature. At steady state, $P$ should exceed unity if reactions other than (3) convert $\mathrm{NO}$ to $\mathrm{NO}_{2}$. With $\mathrm{J}_{\mathrm{NO}_{2}}$ computed from the output of the UV radiometer (equation (1)), all of the parameters required to compute $P$ were measured at this site.

The value of $\mathrm{P}$, computed for $\mathrm{NO}_{\mathrm{x}}$ and $\mathrm{O}_{3}$ measurements taken above the treetops at $6.2,9.5,18.2$, and $30.8 \mathrm{~m}$, is plotted against time of day in Figure 4. We find that $P$ is not strongly dependent on sun angle during most of the daytime nor on $\mathrm{J}_{\mathrm{NO}_{2}}$ (not shown). During typical midday conditions, $\mathrm{J}_{\mathrm{NO}_{2}}=0.0055 \mathrm{~s}^{-1}$ and $\mathrm{P}=2.9$ (medians for 1200-1400 EST). These results indicate that reactions of $\mathrm{NO}$ with compounds other than $\mathrm{O}_{3}$ play an important role in determining the ratio of $\mathrm{NO}_{2}$ to $\mathrm{NO}$ at this site, in agreement with the other measurements in the rural and remote troposphere [Ritter et al., 1979; Kelly et al., 1980; Parrish et al., 1986; Ridley et al., 1992].

Reaction of $\mathrm{NO}$ with peroxy radicals $\left(\mathrm{HO}_{2}\right.$ and $\mathrm{RO}_{2}$, where $\mathrm{R}$ represents an organic group) would lead to a value of $P>1$. The peroxy radical abundance required to produce the observed departure from the simple photochemical steady state of (3)-(5) is given approximately by

$$
\left[\mathrm{HO}_{2}\right]+\left[\mathrm{RO}_{2}\right]=\left[\mathrm{O}_{3}\right](\mathrm{P}-1)\left[\frac{\mathrm{k}}{\mathrm{k}^{\prime}}\right]
$$

where $\mathrm{k}^{\prime}$ is the rate constant for the reaction of $\mathrm{NO}$ with $\mathrm{HO}_{2}$ (note that the rate constants for reaction of $\mathrm{NO}$ with $\mathrm{HO}_{2}, \mathrm{CH}_{3} \mathrm{O}_{2}$, and $\mathrm{C}_{2} \mathrm{H}_{5} \mathrm{O}_{2}$ are similar [Demore et al., 1990]). The computed peroxy radical mixing ratios are shown in Figure 5. At midday we find that $\mathrm{HO}_{2}+\mathrm{RO}_{2}=71$ (median, quartiles $=28$ and 153) pptv. About half of the variance in the computed peroxy radical mixing ratios is explained by a linear relationship with $\mathrm{J}_{\mathrm{NO}_{2}}$ (Figure 6), and the relationship between $\mathrm{HO}_{2}+\mathrm{RO}_{2}$ and $\mathrm{J}_{\mathrm{NO}_{2}}$ is very similar to that reported by Parrish et al. [1986] at Niwot Ridge, Colorado, for summer periods with $\mathrm{NO}_{\mathrm{x}}$ mixing ratios between 250 and 1000 pptv. However, $\mathrm{NO}_{\mathrm{x}}$ levels at our site are much lower that at Niwot Ridge, rarely exceeding $150 \mathrm{pptv}$, and we find no significant relationship between peroxy radicals and $\mathrm{NO}_{\mathrm{x}}$ at our site. The latter result is in agreement with the observations of Ridley et al. [1992],

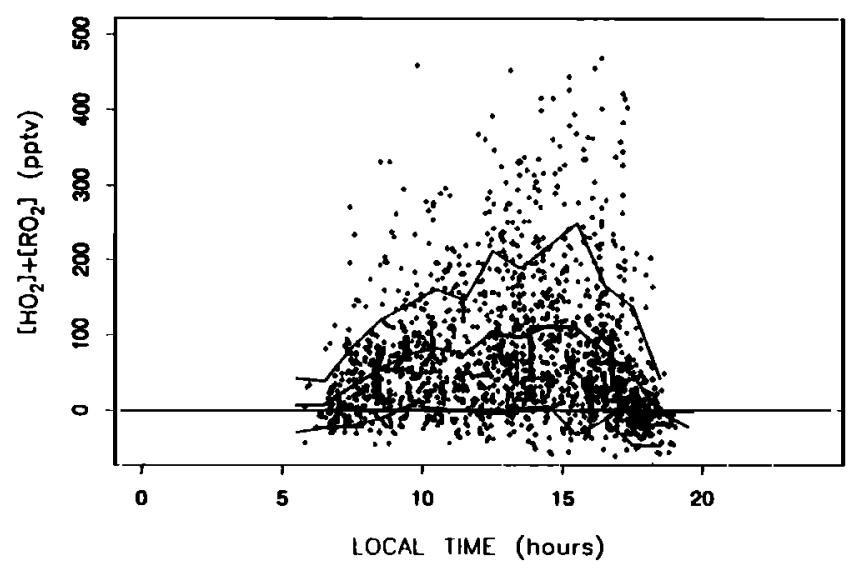

Fig. 5. Computed (equation (7)) peroxy radical mixing ratios $\left(\mathrm{HO}_{2}+\mathrm{RO}_{2}\right)$ required to explain observed $\mathrm{NO} / \mathrm{NO}_{2}$ ratios, plotted against time of day. Hourly means ( \pm 1 s.d.) are shown by the dotted curves.

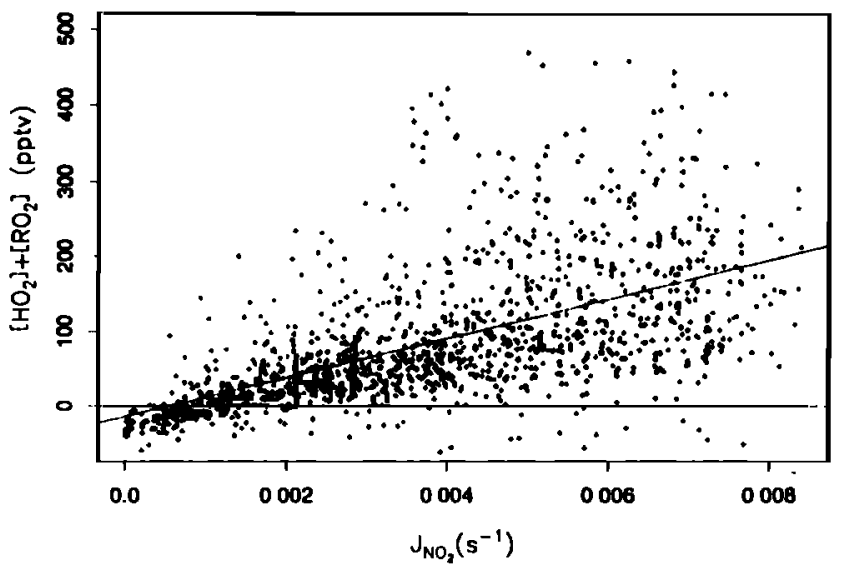

Fig. 6. Computed peroxy radical mixing ratios (equation (7)) required to explain observed $\mathrm{NO} / \mathrm{NO}_{2}$ ratios, plotted against the $\mathrm{NO}_{2}$ photolysis rate,

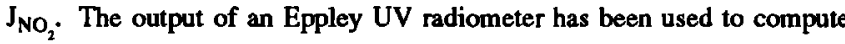
$\mathrm{J}_{\mathrm{NO}_{2}}$ following Madronich [1987], as outlined in the text. The slope of the regression line is 26240 pptv*s, $\mathrm{R}^{2}=0.37$.

which were also obtained at a remote (low $\mathrm{NO}_{\mathrm{x}}$ ) site. The strong relationship between computed peroxy radical levels and UV radiation $\left(\mathrm{J}_{\mathrm{NO}_{2}}\right)$ is expected, since peroxy radical production is photochemically controlled. Our findings for the ABLE 3B forest site differ significantly from those for the ABLE $3 A$ tundra site where biogenic hydrocarbon emissions and peroxy radical production rates were relatively slow [Jacob et al., 1992].

\section{2. $N O_{x} / N O_{y}$ Ratios}

Ratios of $\mathrm{NO}_{\mathrm{x}}$ to $\mathrm{NO}_{\mathrm{y}}$ obtained on the tower and aboard the Electra when flying in the PBL over northeast Canada show very similar distributions (Figure 7). The ratios are remarkablely constant over the range of $\mathrm{NO}_{\mathrm{y}}$ mixing ratios sampled and the means $( \pm$ s.d.) for the tower $(0.20 \pm 0.10, n=808)$ and aircraft $(0.19 \pm 0.09$, $\mathrm{n}=268$ ) are very similar. These low ratios indicate that fresh inputs of $\mathrm{NO}_{\mathbf{x}}$ had not occurred recently relative to the $\mathrm{NO}_{\mathrm{x}}$ lifetime (about 1 day). The $\mathrm{NO}_{\mathrm{x}} / \mathrm{NO}_{\mathrm{y}}$ ratios appear to increase somewhat at the lowest $\mathrm{NO}_{\mathrm{y}}$ abundances, but this may be due in part to random measurement errors at low $\mathrm{NO}_{\mathrm{x}}$ and $\mathrm{NO}_{\mathrm{y}}$. Data obtained during ABLE 3A over the tundra of SW Alaska also showed lower $\mathrm{NO}_{\mathrm{x}} / \mathrm{NO}_{\mathrm{y}}$ ratios, $0.08( \pm 0.02$, also apparently uncorrelated with the mixing ratio of $\mathrm{NO}_{\mathrm{y}}$ [Bakwin et al., 1992], indicating important differences between processes that control $\mathrm{NO}_{\mathrm{x}}$ mixing ratios in these two regions.

\section{Discussion}

The low mixing ratios of $\mathrm{NO}_{\mathrm{x}}, \mathrm{NO}_{\mathrm{y}}$, and $\mathrm{O}_{3}$ and the low $\mathrm{NO}_{\mathrm{x}} / \mathrm{NO}_{\mathrm{y}}$ ratios observed confirm that this woodland site is indeed remote from direct industrial influence. During periods when "background" (Arctic) air was sampled, $\mathrm{NO}_{\mathrm{y}}$ mixing ratios (generally 180-340 pptv) were among the lowest seen at any continental location, and were similar to levels we observed at a tundra site in southwest Alaska during ABLE 3A [Bakwin et al., 1992]. NOx mixing ratios were also low in "background" (Arctic) air, typically 20-40 pptv, but were 2-3 times higher than at the ABLE 3A tundra site. Background $\mathrm{NO}_{\mathrm{x}}$ levels at the taiga site were near the expected crossover point for net production/destruction of $\mathrm{O}_{3}$ by photochemistry.

Elevated mixing ratios of $\mathrm{NO}_{x}, \mathrm{NO}_{y}$, and $\mathrm{O}_{3}$ were observed episodically at both the tundra (ABLE 3A [Bakwin et al., 1992]) and 

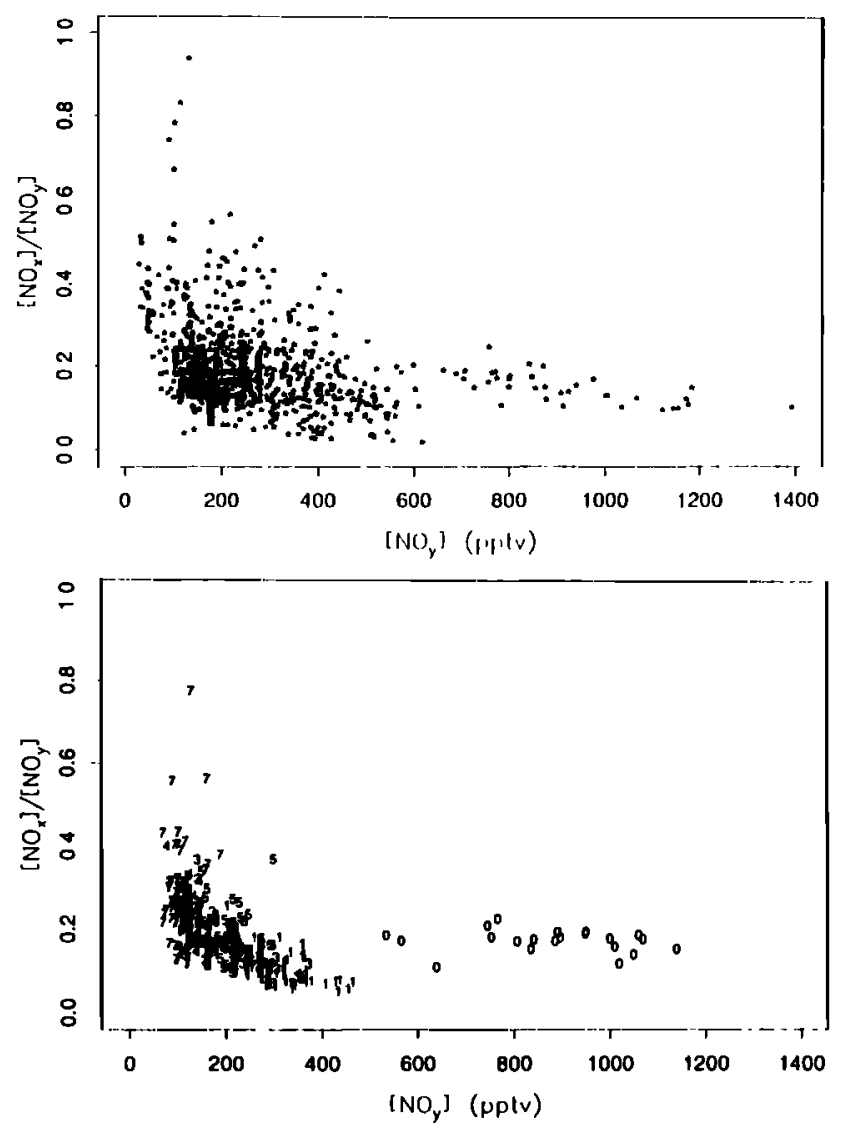

Fig. 7. $\mathrm{NO}_{\mathrm{x}} / \mathrm{NO}_{\mathrm{y}}$ plotted against $\mathrm{NO}_{\mathrm{y}}$ for data obtained $(a)$ at the Schefferville tower, and $(b)$ in the planetary boundary layer $(\mathrm{PBL})$ by instruments aboard the NASA Electra aiplane. Aircraft data are shown by numbers with 0-7 indicating data from missions 10-17, respectively (excluding mission 16). No data were obtained in the PBL during mission 12 due to equipment failure.

taiga (ABLE 3B) sites associated with pollution from industrial and/or biomass-burning sources. Pollution events are especially evident in the ABLE 3B data set (Figure 1). It is difficult or impossible to separate the effects of industrial processes from those of biomass fires on the basis of the $\mathrm{NO}_{\mathbf{x}}, \mathrm{NO}_{\mathbf{y}}$, and $\mathrm{O}_{3}$ data alone, however the hydrocarbon and halocarbon data (Table 2) clearly indicate that industrial pollution is a source for trace gases measured at the taiga woodland site. Future studies should include measurements of "fingerprint" compounds such as $\mathrm{C}_{2} \mathrm{Cl}_{4}$ simultaneous with nitrogen oxide and $\mathrm{O}_{3}$ measurements.

Our finding of an important industrial pollution influence is somewhat counter to that of Talbot et al. [this issue], who concluded that biomass burning was the main source of elevated $\mathrm{NO}_{\mathrm{K}}$ and $\mathrm{NO}_{\mathrm{y}}$ mixing ratios sampled aboard the Electra. This difference is likely due to differences in the data sets addressed in the two papers. In particular, Talbot et al. excluded from their analysis the industrial pollution episode encountered in the PBL during mission 10 (as well as industrial pollution encountered in the marine boundary layer off northeast Canada during mission 16), and they focused largely on data above the PBL. The tower data clearly show that the episode on days 209-211 was not unique, reflecting a pattern that repeated several times. The meteorological conditions leading to transport of industrial pollution from the Great Lakes region (i.e., high pressure over much of northeast Canada) are associated with subsidence, and results from the three-dimensional chemical tracer model (CTM) of Jacob et al. [1993] show that essentially all of the transport of industrial pollution occurs in the PBL.

In the CTM, roughly $5 \%\left(0.9 \times 10^{9} \mathrm{~g} \mathrm{~N} \mathrm{~d}^{-1}\right)$ of the $\mathrm{NO}_{\mathrm{x}}$ emitted by industrial sources in the United States and Canada is transported to the Arctic northward of $60^{\circ} \mathrm{N}$ during summer. This is approximately equivalent to each of the sources of $\mathrm{NO}_{\mathrm{x}}$ to the Arctic troposphere from biomass burning [Jacob et al., 1992; Wofsy et $a l$., this issue] and from the stratosphere [Jacob et al., 1992]. North American sources supply approximately $35 \%$ of the global source of $\mathrm{NO}_{x}$ from industrial processes, and a large portion of the remainder is emitted at midlatitudes in Europe and Asia. If a similar fraction (5\%) of emissions from all industrial sources is exported to or emitted in the Arctic, the total industrial source of $\mathrm{NO}_{\mathrm{y}}$ to the Arctic in summer would be about $2.6 \times 10^{9} \mathrm{~g} \mathrm{~N} \mathrm{~d}^{-1}$. Examination of statistics for $\mathrm{NO}_{\mathrm{x}}$ emission from industrial sources compiled by Hameed and Dignon [1988] indicates that the 5\% estimate may be reasonable for Europe and Asia, where industrial centers reside farther north than in North America.

Measured wet and dry deposition of $\mathrm{NO}_{\mathrm{y}}$ at our site totaled about $35 \mathrm{~g} \mathrm{~N} \mathrm{ha}^{-1}$ month $^{-1}$ (M93), very similar to deposition rates at the ABLE 3A tundra site at $62^{\circ} \mathrm{N}\left(36 \mathrm{~g} \mathrm{~N}^{-1}\right.$ month $^{-1}$ [Bakwin et al., 1992; Talbot et al., 1992]). If we assume that deposition rates measured at these two sites are representative of the world northward of $60^{\circ} \mathrm{N}\left(3.4 \times 10^{\circ} \mathrm{ha}\right)$ in summer, we would calculate a deposition flux of $4.0 \times 10^{9} \mathrm{~g} \mathrm{~N} \mathrm{~d}^{-1}$, giving a rough budget for $\mathrm{NO}_{\mathrm{y}}$ for the Arctic troposphere in summer. Sources from industrial pollution ( $2.6 \times 10^{9} \mathrm{~g} \mathrm{~N} \mathrm{~d}^{-1}$ ) would account for $\approx 50 \%$ of the total, with the balance from biomass burning $(0.9)$ and the stratospheric input (0.9), approximately balanced by wet and dry deposition (4.0). Mixing ratios of $\mathrm{NO}_{\mathrm{y}}$ observed in the Arctic are much higher in winter than in summer due to increased transport from midlatitudes and reduced loss rates [Honrath and Jaffe, 1992].

Levels of $\mathrm{NO}_{\mathrm{x}}$ in the PBL were low under background conditions (20-40 pptv), leading to slow rates of net photochemical production of $\mathrm{O}_{3}$, about $0.8 \mathrm{ppbv}^{\text {day }}{ }^{-1}$ (S. M. Fan et al., manuscript in preparation, 1993, hereinafter referred to as F93). Loss of $\mathrm{O}_{3}$ by deposition to the surface was somewhat larger, about $1.6 \mathrm{ppbv}$ $\mathrm{d}^{-1}$ (M93). Intervals with $\mathrm{NO}_{\mathrm{x}}$ levels in the range 50-150 pptv, persisting for several days, were observed at this site; the elevated $\mathrm{NO}_{\mathrm{x}}$ was contributed at least in part by industrial pollution from the Great Lakes region of the United States and Canada. Biomass fires may also have played a role but cannot be unambiguously distinguished. Periods of elevated $\mathrm{NO}_{\mathbf{x}}$ were associated with elevated $\mathrm{O}_{3}$ (Figure 1), and the CTM results [Jacob et al., 1993] indicate that the $\mathrm{O}_{3}$ enhancements could result from enhanced photochemical production (or suppressed loss) within the industrial pollution plumes. Potential $\mathrm{O}_{3}$ production rates are much greater at this site than at the ABLE 3A tundra site due to higher mixing ratios of large amounts of biogenic hydrocarbons at this site.

$\mathrm{NO}_{\mathrm{x}}$ levels during a 3-week period of generally fair weather and southwesterly flow (Julian days 197-221, Table 1) were on average twice those observed during cooler periods of westerly and northwesterly flow (178-196 and 222-229). Higher $\mathrm{NO}_{\mathrm{x}}$ is expected to lead to greater net production of $\mathrm{O}_{3}$; however, $\mathrm{O}_{3}$ levels were not significantly different between these two broad intervals. Southwesterly flow is generally associated with subsidence, with strongly capped PBLs [Fitzjarrald and Moore, this issue], so that the supply of $\mathrm{O}_{3}$ from aloft may be reduced. Also, since the loss of $\mathrm{O}_{3}$ by surface deposition is about twice as fast as photochemical production, our result is perhaps not surprising. Further, the periods of strongest southwesterly flow and highest levels of industrial pollution, such as the episodes of days 209-211 and day 
221, we observed a clear enhancement of $\mathrm{O}_{3}$ over background levels (Figure 1). The overall impact of industrial pollution on regional $\mathrm{O}_{3}$ levels is moderated by the rapid loss of $\mathrm{NO}_{x}$ within the PBL and by deposition of $\mathrm{O}_{3}$ to the surface.

We find that $\mathrm{NO} / \mathrm{NO}_{2}$ ratios observed at the taiga site are not well described by a simple photochemical steady state involving only $\mathrm{NO}_{x}$ and $\mathrm{O}_{3}$, indicating that other oxidants are important in converting $\mathrm{NO}$ to $\mathrm{NO}_{2}$. Peroxy radicals produced from isoprene oxidation are likely the major cause of low the $\mathrm{NO} / \mathrm{NO}_{2}$ ratios (F93). Oxidation of $\mathrm{NO}$ by $\mathrm{O}_{3}$ alone is sufficient to explain $\mathrm{NO} / \mathrm{NO}_{2}$ ratios we observed at the tundra site during ABLE $3 \mathrm{~A}$ [Bakwin, 1989], consistent with estimates of low peroxy radical mixing ratios and production rates from hydrocarbon precursors [Jacob et al., 1992].

Though $\mathrm{NO}_{\mathrm{y}}$ levels were similar in "background" air at the tundra (ABLE 3A) and taiga (ABLE 3B) sites, $\mathrm{NO}_{\sqrt{x}} \mathrm{NO}_{\mathrm{y}}$ ratios were 2-3 times higher at the taiga site. Further, $\mathrm{PAN} / \mathrm{NO}_{\mathrm{y}}$ ratios were much higher in the PBL over the taiga site (0.2-0.5 [Sandholm et $a l$., this issue]) than over the tundra site $(\approx 0.05$ [Sandholm et al., 1992]). These results likely reflect differences in the $\mathrm{NO}_{\mathbf{x}}$ budgets at these locations. At the tundra site the balance between PAN decomposition and $\mathrm{HNO}_{3}$ formation appears to regulate $\mathrm{NO}_{\mathbf{x}}$ levels [Jacob et al., 1992]. This balance must also hold for the taiga site, since the essentially all of the $\mathrm{NO}_{\mathrm{y}}$ measured in the PBL is accounted for by observed species (i.e., $\mathrm{NO}_{\mathbf{x}}, \mathrm{PAN}, \mathrm{HNO}_{3}$, and $\mathrm{NO}_{3}^{-}$) [Sandholm et al., this issue]. A major difference between these two sites is the relatively high isoprene emission rates from the taiga vegetation (isoprene emissions from the tundra were essentially zero). Trainer et al. [1991] found that increasing isoprene emissions in their photochemical model of the rural PBL caused a shift of $\mathrm{NO}_{x}$ oxidation from $\mathrm{HNO}_{3}$ to organic nitrates, including PAN. The reason for this is threefold: (1) increased isoprene leads to higher rates of peroxy acetyl (PA) radical production during the daytime, suppressing the decomposition of PAN; (2) peroxy radicals from isoprene oxidation convert NO to $\mathrm{NO}_{2}$, leading to an increase in the $\mathrm{NO}_{2} / \mathrm{NO}$ ratio and further limiting PAN decomposition; and (3) isoprene and its oxidation products compete directly with $\mathrm{NO}_{2}$ for reaction with $\mathrm{OH}$, so that $\mathrm{HNO}_{3}$ formation is reduced as isoprene levels are increased. The results of Trainer et al. [1991] are in harmony with our comparison of the ABLE tundra and taiga sites; the local biota appear to exert a strong influence on $\mathrm{NO}_{2} / \mathrm{NO}$ and $\mathrm{PAN} / \mathrm{NO}$ y ratios. These ideas are being explored further through photochemical modeling of the ABLE 3B data set (F93).

Ratios of $\mathrm{NO}_{\mathrm{x}}$ to $\mathrm{NO}_{\mathrm{y}}$ measured at a rural site in Pennsylvania during the daytime in summer were also about 0.2 , though $\mathrm{NO}_{\mathrm{z}}$ and $\mathrm{NO}_{\mathrm{y}}$ mixing ratios were much higher than at our taiga site due to the proximity to emissions [Buhr el al., 1990]. At night at the Pennsylvania site, $\mathrm{NO}_{\mathrm{x}} / \mathrm{NO}_{\mathrm{y}}$ ratios increased to $0.6-0.8$ as $\mathrm{NO}_{\mathrm{x}}$ emissions continued with reduced rates of conversion to higher oxides [Trainer et al., 1991]. At our site no such nocturnal increase in $\mathrm{NO}_{\mathbf{x}} / \mathrm{NO}_{\mathrm{y}}$ was observed. These results indicate that the approach to equilibrium between $\mathrm{NO}_{x}$ and $\mathrm{NO}_{y}$ is achieved in a few hours under conditions of vigorous photochemical activity and may be maintained for at least several days, even as $\mathrm{NO}_{\mathbf{y}}$ is depleted by dilution and deposition. At sites where reactive hydrocarbons are not abundant, such as the Mauna Loa Observatory (MLO) [Carroll et al., 1992] and our ABLE 3A tundra site [ Bakwin et al., 1992], equilibrium $\mathrm{NO}_{\mathrm{z}} / \mathrm{NO}_{\mathrm{y}}$ ratios are somewhat lower, typically around 0.1 .

The difference may be explained in part by the by the relative abundance of "missing" $\mathrm{NO}_{\mathrm{y}}$ species (i.e., $\left[\mathrm{NO}_{\mathrm{y}}\right]$ $\left.\left(\left[\mathrm{NO}_{\mathrm{x}}\right]+\left[\mathrm{HNO}_{3}\right]+\left[\mathrm{NO}_{3}\right]+[\mathrm{PAN}]\right)\right)$. At $\mathrm{MLO}$, about $25 \%$ of $\mathrm{NO}_{\mathrm{y}}$ is "missing" during downslope periods [Atlas et al., 1992], at our ABLE 3A site about half of the observed $\mathrm{NO}_{y}$ is "missing" and appears to consist of fairly stable species that are resistant to deposition [Bakwin et al., 1992]. At the Pennsylvania site [Buhr et al., 1990] and our ABLE 3B taiga site [Sandholm et al., this issue], nearly all of $\mathrm{NO}_{\mathrm{y}}$ is accounted for by measured species. This comparison may indicate that the "missing" $\mathrm{NO}_{\mathrm{y}}$ species do not play a major role in the budgets of $\mathrm{NO}_{\mathrm{x}}$ at these sites.

Acknowledgments. This work was supported by NASA grant NAG1-55 to Harvard University and by the Alexander Host Foundation. We are grateful to $\mathrm{M}$. Shipham for useful discussions concerning the meteorological context for these measurements, to J. Barrick for loan of the calibrated UV radiometer, and to S. Fan for belpful discussions conceming photochemistry at the ABLE 3B site. We also thank D. Barr and A. McNally of the McGill Subarctic Research Station, J. Drewry of NASA Langley Research Center, and D. Fitzjarrald and K. Moore of the State University of New York (Albany) for their efforts in the field.

\section{REFERENCES}

Atlas, E.L., B.A. Ridley, G. Hubler, J.G. Walega, M.A. Carroll, D.D. Montzka, B.J. Huebert, R.B. Norton, F.E. Grahek, and S. Schauffer, Partitioning and budget of $\mathrm{NO}_{\mathrm{y}}$ species during the Mauna Loa Observatory Photochemistry Experiment, J. Geophys. Res., 97, 10,449-10,162, 1992.

Bakwin, P.S., Reactive nitrogen oxides in remote areas: Atmospheric concentrations and atmosphere/biosphere exchange, Ph.D. thesis, Div. of Appl. Sci., Harvard Univ., Cambridge, Mass., 1989.

Bakwin, P.S., S.C. Wofsy, and S.M. Fan, Measurements of $\mathrm{NO}_{x}$ and $\mathrm{NO}_{y}$ concentrations and fluxes over Arctic tundra, J. Geophys. Res., 97, $16,545-16,557,1992$.

Blake, D. R., T.W. Smith, Jr., T.-Y. Chen, W. J. Whipple, and F.S. Rowland, Effects of biomass burning on summertime nonmethane hydrocarbons in the Canadian wetlands, J. Geophys. Res., this issue.

Bojkov, R.D., Ozone changes at the surface and in the free troposphere, in Tropospheric Ozone, edited by I.S.A. Isaksen, pp. 83-96, D. Reidel, Norwell, Mass., 1988.

Buhr, M.P., D.D. Parrish, R.B. Norton, F.C. Fehsenfeld, R.E. Sievers, and J.M. Roberts, Contribution of organic nitrates to the total reactive nitrogen budget at a rural eastem U.S. site, J. Geophys. Res., 95, 9809-9816, 1990.

Carroll, M.A., B.A. Ridley, D.D. Montzka, G. Hubbler, J.G. Walega, R.B. Norton, B.J. Huebert, and F.E. Grahek, Measurements of nitric oxide and nitrogen dioxide during the Manna Loa Observatory Photochemistry Experiment, J. Geophys. Res., 97, 10,361-10,374, 1992.

Demore, W.B., S.P. Sander, D.M. Golden, M.J. Molina, R.F. Hampson, M.J. Kurylo, C.J. Howard, and A.R. Ravishankara, Chemical kinetics and photochemical data for use in stratospheric modeling, JPL Pub. 901, Calif. Inst. of Technol., Pasadena, Calif., 1990.

Fahey, D.W., C.S. Eubank, G. Hubler, and F.C. Fehsenfeld, Evaluation of a catalytic reduction technique for the measurement of total reactive odd-nitrogen $\left(\mathrm{NO}_{\mathrm{y}}\right)$ in the atmosphere, J. Atmos. Chem., 3, 435-468, 1986.

Ferguson, E.E., and R.M. Rosson (Eds.), Climate monitoring and diagnostics laboratory, Summ. Rep. 20, 1991, Natl. Oceanic and Atmos. Admin., Boulder, Colo., 1992.

Fitzjarrald, D.R., and K.E. Moore, Growing season boundary layer climate and surface exchanges in the northem subarctic woodland, J. Geophys. Res., this issue.

Hanson, J., G. Russell, D. Rind, P. Stone, A. Lacis, S. Lebedeff, R. Ruedy, and $L$. Travis, Efficient three-dimensional global models for climate studies: Models I and II, Mon. Weather Rev., 11I, 609-662, 1983.

Hameed, S., and J. Dignon, Changes in the geographical distributions of global emissions of $\mathrm{NO}_{\mathrm{x}}$ and $\mathrm{SO}_{\mathrm{x}}$ from fossil fuel combustion between 1966 and 1980, Atmos. Environ., 22, 441-449, 1988. 
Honrath, R.E., and D.A. Jaffe, The seasonal cycle of nitrogen oxides in the arctic troposphere at Barrow, Alaska, J. Geophys. Res., 97, 20,61520,630, 1992.

Jacob, D.J., et al., Summertime photochemistry of the troposphere at high northern latitudes, J. Geophys. Res., 97, 16,421-16,432, 1992.

Jacob, D.J., et al., Climatological simulations of summertime ozone over North America, J. Geophys. Res., 98, 14,797-14,816, 1993.

Kelly, T.J., D.H. Stedman, J.A. Ritter, and R.B. Harvey, Measurements of oxides of nitrogen and nitric acid in clean air, J. Geophys. Res., 85, 7417-7425, 1980.

Liu, S.C., M. Trainer, F.C. Fehsenfeld, D.D. Parrish, E.J. Williams, D.W. Fahey, G. Hubler, and P.C. Murphy, Ozone production in the rural troposphere and the implications for regional and global ozone distributions, J. Geophys. Res., 92, 4192-4207, 1987.

Logan, J.A., Nitrogen oxides in the troposphere: Global and regional budgets, J. Geophys. Res., 88, 10785-10807, 1983.

Logan, J.A., M.J. Prather, S.C. Wofsy, and M.B. McElroy, Tropospheric chemistry: A global perspective, J. Geophys. Res., 86, 7210-7254, 1981.

Madronich, $\mathrm{S}$., Intercomparison of $\mathrm{NO}_{2}$ photodissociation and U.V. radiometer measurements, Atmos. Environ., 21, 569-578, 1987.

Oltmans, S.J., and W.D. Komhyr, Surface ozone distributions and variations from 1973-1984 measurements at the NOAA geophysical monitoring for climatic change baseline observations, J. Geophys. Res., 91, 5229-5236, 1986.

Parrish, D.D., M. Trainer, E.J. Williams, D.W. Fahey, G. Hubler, C.S. Eubank, S.C. Liv, P.C. Murphy, D.L. Albritton, and F.C. Fehsenfeld, Measurements of the $\mathrm{NO}_{\mathrm{x}}-\mathrm{O}_{3}$ photostationary state at Niwot Ridge, Colorado, J. Geophys. Res., 91, 5361-5370, 1986.

Ridley, B.A., M.A. Carroll, G.L. Gregory, and G.W. Sachse, NO and $\mathrm{NO}_{2}$ in the troposphere: Technique and measurements in regions of a folded tropopause, J. Geophys. Res., 93, 15,813-15,830, 1988.

Ridley, B.A., S. Madronich, R.B. Chatfield, J.G. Walega, R.E. Shetter, M.A. Carroll, and D.D. Montzka, Measurements and model simulations of the photostationary state during the Mauna Loa Observatory Photochemistry Experiment: Implications for radical concentrations and ozone production and loss rates, J. Geophys. Res., 97, 10,375-10,388, 1992.

Ritter, J.A., D.H. Stedman, and T.J. Kelly, Ground level measurements of nitric oxide, nitrogen dioxide and ozone in nural air, in Nitrogenous Air Pollutants: Chemical and Biological Implications, edited by D. Grosjean, Butterworth, Stoneham, Mass., 1979.

Sandholm, S.T., et al., Summertime tropospheric observations related to $\mathrm{N}_{\mathrm{x}} \mathrm{O}_{\mathrm{y}}$ distributions and partitioning, J. Geophys. Res., 97, 16,481-16,510, 1992.

Sandholm, S.T., et al., Summertime partitioning and budget of $\mathrm{NO}_{y}$ com- pounds in the troposphere over Alaska and Canada: ABLE 3B, J. Geophys. Res., this issue.

Shetter, R.E., A.H. McDaniel, C.A. Cantrell, S. Madronich, and J.G. Calvert, Actinometer and Eppley radiometer measurements of the $\mathrm{NO}_{2}$ photolysis rate coefficient during the Mauna Loa Observatory Photochemistry Experiment, J. Geophys. Res., 97, 10,349-10,360, 1992.

Shipham, M.C., A.S. Bachmeier, D.R. Cahoon, Jr., G.L. Gregory, B.E. Anderson, and E.V. Browell, Meteorological interpretation of the Arctic Boundary Layer Expedition (ABLE) 3B flight series, J. Geophys. Res., this issue.

Spivakovsky, C.M., S.C. Wofsy, and M.J. Prather, A numerical method for parameterization of atmospheric chemistry: computation of tropospheric OH, J. Geophys. Res., 95, 18,433-18,439, 1990.

Talbot, R.W., A.S. Vijgen, and R.C. Hariss, Soluble species in the summer Arctic troposphere: Acidic gases, aerosols, and precipitation, $J$. Geophys. Res., 97, 16,531-16,544, 1992.

Talbot, R.W., et al., Summertime distributions and relations of reactive oddnitrogen species and $\mathrm{NO}_{\mathrm{y}}$ in the troposphere over Canada, J. Geophys. Res., this issue.

Trainer, M., et al., Observations and modeling of the reactive nitrogen photochemistry at a nural site, J. Geophys. Res., 96, 3045-3063, 1991.

Wofsy, S.C., et al., Atmospheric chemistry in the Arctic and subarctic: Influence of natural fires, industrial emissions, and stratospheric inputs, J. Geophys. Res., 97, 16,731-16,746, 1992.

Wofsy, S.C., S.M. Fan, D.R. Blake, J.D. Bradshaw, S.T. Sandholm, H.B. Singh, G.W. Sachse, and R.C. Harriss, Factors influencing of atmospheric composition over subarctic North America during summer, J. Geophys. Res., this issue.

P. S. Bakwin, Climate Monitoring and Diagnostic Laboratory, NOAA, 325 Broadway, Boulder, CO 80303.

D. R. Blake, Department of Chemistry, University of Califomia, Irvine, CA 92717.

J. D. Bradshaw and S. T. Sandholm, School of Atmospheric Sciences, Georgia Institute of Technology, Atlanta, GA 30332.

B. C. Daube, D. J. Jacob, J. W. Munger, and S. C. Wofsy, Division of Applied Sciences, Harvard University, Cambridge, MA 02138.

G. L. Gregory, NASA Langley Research Center, Hampton, VA 23665.

H. B. Singh, NASA Ames Research Center, Moffett Field, CA 94035.

R. W. Talbot, Complex Systems Research Center, University of New Hampshire, Durham, NH 03824.

(Received August 12, 1992; revised August 10, 1993; accepted August 10, 1993) 